TOTOBUANG

\begin{tabular}{|lll}
\hline Volume 6 & Nomor 2, Desember 2018 & Halaman 257-267 \\
\hline
\end{tabular}

\title{
PEMIKIRAN KRITIS ELIZABETH BENNET DAN FITZWILLIAM DARCY DALAM PRIDE AND PREJUDICE KARYA JANE AUSTEN (The Critical Thinking of Elizabeth Bennet and Fitzwilliam Darcy in Jane Austen's Pride and Prejudice)
}

\author{
Eduardus Mungan ${ }^{a, *} \&$ Citra Suryanovika ${ }^{b, *}$ \\ a, b Sekolah Tinggi Bahasa Asing Pontianak \\ Jalan Imam Bonjol No. 82 A-B-C, Pontianak, Indonesia \\ Pos-el: mungan87@gmail.com
}

(Diterima: 12 Oktober 2018; Direvisi 8 November 2018; Disetujui: 14 November 2018)

\begin{abstract}
This study discussed about the critical thinking of the main characters, Elizabeth Bennet and Fitzwilliam Darcy, in the Jane Austen's novel Pride and Prejudice. This study aimed to identify the characters' arguments based on the categories of critical thinking of the characters, the kinds of arguments in critical thinking, and to describe the usage of meaning as discourse strategy and the usage of discourse markers in the characters' argument in Pride and Prejudice. This study used critical thinking theory and discourse analysis in collecting the data acquired by transcribing the texts in Pride and Prejudice. In this study, the researcher used descriptive qualitative method to interpret the analysis data. The results of this study shows that the categories of critical thinking of the main characters in Pride and Prejudice are definitely high, the kinds of arguments in critical thinking used by the main characters are mostly inductive arguments rather than deductive arguments, the usage of meaning is definitely various based on the argument's topic, and the usage of the discourse markers in the main characters' argument is definitely different in usage records based on the intention of the main characters' utterances.
\end{abstract}

Keywords: Critical thinking, discourse, argument

Abstrak

Penelitian ini membahas tentang pemikiran kritis dari tokoh utama, Elizabeth Bennet dan Fitzwilliam Darcy, dalam novel Pride and Prejudice karya Jane Austen. Penelitian ini bertujuan untuk mengidentifikasi argumen para karakter tersebut, jenis argument dalam berpikir kritis, dan mendeskripsikan penggunaan makna dan penggunaan penanda wacana dalam Pride and Prejudice. Penelitian ini menggunakan teori berpikir kritis dan analisis wacana dalam mengumpulkan data. Sumber data diperoleh dengan mencatat teks-teks dalam Pride and Prejudice. Karena itu, peneliti menggunakan metode deskriptif kualitatif dalam menafsirkan data analisis. Hasil penelitian ini menunjukkan bahwa kategori berpikir kritis dari tokoh utama dalam Pride and Prejudice sangat tinggi, jenis argumen dalam pemikiran kritis yang digunakan oleh tokoh utama mayoritas merupakan argumen induktif daripada argumen deduktif, penggunaan makna sangat bervariasi berdasarkan topik argumen, dan penggunaan penanda wacana dalam argumen tokoh utama sangat berbeda dalam jumlah penggunaan berdasarkan maksud dari ujaran tokoh utama.

Kata-kata kunci: Berfikir kritis, wacana, argumen

\section{INTRODUCTION}

Critical thinking is a skill that requires a personal interpretation not only by expressing that the argument is true or false but also by thinking positively toward the argument. That is a fair thinking because the skill does not intend to critic the others' argument, which can be accepted through the acceptable, relevance and good argument
(Govier, 2010:87). Because of that, this situation can also be explored and studied through a literary work especially a novel which delivers many statements or arguments from each character inside the novel.

Some of characters' personality can be implicitly found not only through their descriptive stories or actions but also 
through their arguments when they are having conversation to the others in the novel. The arguments can illustrate the characters' critical thinking when they are acquiring, analyzing and responding to other ideas or arguments. Therefore, the characters' thinking skill can be further analyzed and studied through how the characters critically respond beyond their arguments.

Elisabeth and Darcy (the two main characters of Jane Austen's Pride and Prejudice), for example, have difficulties to understand each other at first but through their rational thinking and experiences, which are illustrated inside the novel, they finally admit their position and be able to adapt to each other. Some recent studies concerned on the literary criticism about Pride and Prejudice have found that there are some different results based on the problem of the study and their approaches. In the result of Wang \& Liu's study in Analysis of the Feminism in Pride and Prejudice (2011), Jane Austen concerned female as the center part of the novel and she lets her female characters that are as independent rather than dependent, described the story as their daily life. Meanwhile, Sheber in Intersections and Implications of Feminist and Marxist Critical Theory in Jane Austen: Persuasion, Pride and Prejudice, and Mansfield Park (2010) described that "through the perspectives of feminist and Marxist critical theory, stated that Austen's works as an effective lens for evaluating a society." In concerning to an adaptation study, Graham in Jane Austen: A Study of Film Adaptations (2011) concludes that the novels of Jane Austen have inspired some film adaptations, which bring the director to modernize the plot and characters to attract and to help connecting the gap between the classic era and modern day.

In analyzing Pride and Prejudice in this study, the writer uses the discourse analysis to explore and to comprehend the meaning or the purpose of the characters' arguments. Meanwhile, the critical thinking theory will be used to acquire and to identify the types of the arguments used by the main characters as the final result to indicate the meaning related to the critical thinking of the main characters. As comparison, Khatib and Alizade, in their study of Critical Thinking through Literary and Non-Literary Texts in English Classes (2012), has concluded that to read between lines, the tools and techniques are more advanced like being competent, learners should learn how to produce and receive information through language critically. Meanwhile, Stab \& Gurevych in Identifying Argumentative Discourse Structures in Persuasive Essays (2014) explains that there are two identifications used in the research, which are identification of argument component and identification of argumentative relation. Therefore, the writer uses the critical thinking theory and the discourse analysis to investigate the critical thinking of the characters and to receive some information from the usage or arguments which is related to the critical thinking process.

In this study, the writer uses the critical thinking theory to identify the critical thinking of the main characters such as the categories and the kinds of arguments, while the discourse analysis is used to prevent the generous scope of the study about the arguments. Therefore, this study is intended to investigate (1) the category of critical thinking (clarity, precision, accuracy, relevance, breadth and consistency, depth and completeness, logic, and fairness) according to Paul and Elder (2009:10), (2) the kinds of argument in the critical thinking such as deductive and inductive argument according to Waller (2012:19), (3) the kinds of discourse strategy according to van Dijk (cited in Rosdiana, 2016:43-44) such as implication, presupposition, evidentially and disclaimer, and (4) the usage of discourse markers according to Halliday and Hasan (cited in Flowerdew, 2013:38) such as 
additive (and, in addition, besides, furthermore), adversative (but, yet, though, however), causal (so, then, therefore), and temporal (then, next, after that, finally) through the characters' arguments in the whole story of Pride and Prejudice as the object of the study.

\section{LITERATURE REVIEW Critical Thinking}

Critical thinking, according to Bassham et al (2011:1), is a term to attain skills and intellectual dispositions to effectively examine arguments about what to believe and what to do. Meanwhile, Waller (2012: xiii) explained that critical thinking is a valuable skill to decide what is to pursue, to buy, to support, and to believe or to reject, which can be very useful. Therefore, it can be defined that critical thinking is a skill of intelligence to examine arguments about what to believe and what to do. Furthermore, in understanding critical thinking, Bowell \& Kemp (2010:56) emphasized that the purpose of critical thinking is intended to learn concepts and techniques about an argument. In the critical thinking, there are two features of argument which are inductive and deductive arguments which inductive argument is the information stated clearly as summary in conclusion while deductive argument is the general conclusion taken from claims as premises (Bassham et al, 2011:77; Waller, 2012:19).

Regarding in developing and applying critical thinking and reading, especially in literary texts, the requirement of critical analysis can be acquired by the critical thinking skill and critical reading skill (Shukri \& Mukundan, 2015; Kohzadi, Azizmohammadi, \& Samadi, 2014; Khatib \& Alizade, 2012; Tung \& Chang, 2009). Because the development of critical thinking has been extremely massive and important, the usage of critical thinking should be considered as the core purpose of thinking skill for every college student. Critical thinking can be described by being fair, active and independent to construct, to identify, to analyze, to evaluate and to clarify information to be a reasonable conclusion (Butterworth \& Thwaites, 2013:1; Moore \& Parker, 2012:2; Bassham, Irwin, Nardone, \& Wallace, 2011:1; Paul \& Elder, 2009).

In critical thinking, an argument consisting of a conclusion and supported by some reasons (premises) is a unique interest, which may require critical responses (Butterworth \& Thwaites, 2013:8; Waller, 2012:14; Moore \& Parker, 2012:37). Furthermore, Govier (2010:1) defined that there are some claims which are placed in the front as premises and the other as conclusion. Those premises are merged by some statements or sentences. It has to be remembered that an argument is different from a statement, because the statement consists of a sentence can be examined from the result as either true or false (Bassham, Irwin, Nardone, \& Wallace, 2011:29). Therefore, in this critical thinking, an argument is extremely significant to identify someone's thinking skill. Because of that, to identify an argument, it can be simply achieved by analyzing the structure of the argument. Generally, the structure of an argument can be described such as:

\section{Premise 1 \\ Premise 2 \\ Premise 3 ... \\ Premise N \\ Therefore, \\ Conclusion (Govier, 2010:3)}

To comprehend this standardization of the argument structure, the following sentence can illustrate what the argument is.

There are no international police. It takes police to thoroughly enforce the law.

Therefore, international law cannot be thoroughly enforced. (Govier, 2010:2) 
In this example, Govier makes the structure of premises and conclusions clearer by setting the argument out as follows:

1. There are no international police.

2. It takes police to thoroughly enforce the law.

Therefore,

3. International law cannot be thoroughly enforced.

In this argument, statements (1) and (2) are put forward to support statement (3) which is the conclusion. The word 'therefore' called indicator as signifier introduces the conclusion (Govier, 2010:2). The signifiers of argument are made easier if the conclusion or reasons are marked by some indicators such as thus, therefore, hence, so, consequently, since, because, this shows that, this implies that and moreover (Butterworth \& Thwaites, 2013:33; Moore \& Parker, 2012:39; Govier, 2010:4-6).

Based on Paul and Elder's description (2009:10) about the universal intellectual standard, it can be simply comprehended that the standard categories refer to the critical thinking, which can be recognized through clarity refers to clarification as in an illustration or example, accuracy refers to correctness as a verification, precision refers to exactness as a specific aspects, relevance refers to importance as a relation of problems, depth refers to complexity as some factors, breadth refers to coverage as another perception, logic refers to reason as a conclusion, significance refers to implication as an association, and fairness refers to consistency as a reliability.

\section{Discourse}

Discourse, according to Flowerdew (2013:1), has an important role in knowledge and language type which generally used by people as in social group. Therefore, since the 1960s, the discourse study which also relates to discourse analysis has many approaches and nowadays it has been emerged as a field of a study or a research such as in the Critical Discourse Analysis
(Angermuller, Maingueneau, \& Wodak, 2014:1-3). The kinds of approaches require the researcher's critical analysis so the result of the study can be explained and discussed completely based on the problem of the study.

In defining discourse, Zarei (2013:108) stated that discourse focuses on the two main ideas such as cause-result or temporal sequence. Because the discourse related to the ideas, the kinds of discourse can be specifically acquired from its meaning as the discourse strategy, which has been stated by van Dijk (cited in Rosdiana, 2016:43-44) such as implication, presupposition, evidentially and disclaimer. Related to the discourse structure, Zhao (2014:2106) stated that there are some Discourse Markers (DMs) related to the coherence relations, marking pauses, transitions, or other aspects of communication. As those explanation, to identify the DMs, there are some kinds of DMs based on Halliday and Hasan which are Additive such as and, in addition, besides, furthermore; Adversative such as but, yet, though, however; Causal such as so, then, therefore, and Temporal such as then, next, after that, finally (Flowerdew, 2013:38).

\section{Research Method}

The object of this study as the primary source of the research is a Jane Austen's novel entitled Pride and Prejudice. This novel is published by Wordsworth Classics in 1993. Formally, the studied object of this study is the characters' arguments divided into the categories of critical thinking of the characters, the kinds of arguments in critical thinking, the usage of discourse meaning as discourse strategy and the usage of Discourse Markers (DMs).

This study uses descriptive qualitative method, which is conducted to comprehend the data analysis specifically related to the research problems in this research. The techniques used to collect the data in this study are by the reading to observe and to determine the required data such as 
sentences or phrases. The sentences or phrases, as the structure of arguments, needs to be analyzed to separate the selected data and to attain the specific result from this study. Because of that, the tools of the data collection are the researcher itself as the primary media, and the note-taking as transcription, which the researcher acquires from the texts in Pride and Prejudice.

The steps of analyzing the data in this study refer to Creswell (2009:185) about qualitative data analysis. Because of that, the description of data analysis in this research are by reading the literary texts as transcription of Pride and Prejudice, identifying the literary texts of Pride and Prejudice through the standardization of argument structure, the discourse strategies, and the Discourse Markers (DMs), understanding the arguments, discourse strategies and Discourse Markers (DMs), collecting the data formed qualitative data and reducing the data to determine which one is required to be analyzed and have to analyze in a cycle process, and drawing or verifying conclusion of the data through interpretation.

\section{DISCUSSION}

This section develops the critical analysis and provides the critical discussion about the description of critical thinking of Elizabeth Bennet and Fitzwilliam Darcy in Pride and Prejudice. The critical thinking of those characters can be analyzed based on the characters' arguments by using the critical thinking theory and the discourse analysis. As comparison, the study of Alfiyatun Nasiroh (2016) discovered some arguments based on the elements of argument such as claim, grounds, warrants, backings, modal qualifiers and possible rebuttals. Meanwhile, this study discovers that there is a different approach to acquire the standardization of argument structure, which discovers some arguments based on the general structure of argument (Govier, 2010:3).
Based on the collected data about the categories of critical thinking in Pride and Prejudice, it is obviously described that the characters' arguments have some differences especially for Elizabeth Bennet and Fitzwilliam Darcy. Their categories of critical thinking can be seen through the standard and valid arguments. Those categories are collected based on the standardization of argument structure, as in sentence(s) or paragraph(s). For Elizabeth Bennet's argument, it can be seen as follows. '... Allow me to say, Lady Catherine, that the arguments with which you have supported this extraordinary application have been as frivolous as the application was ill-judged. (Sig.) You have widely mistaken my character, if you think I can be worked on by such

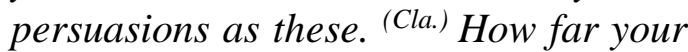
nephew might approve of your interference in his affairs, I cannot tell; but you have certainly no right to concern yourself in mine. (Acc.) I must beg, therefore, to be importuned no farther on the subject.' (Pre.) (Chapter 56 p. 299).

In this argument, there are some categories of critical thinking that can be found such as Significance (Sig.) which is the central idea to focus on Elizabeth Bennet's argument which is about leaving Mr. Darcy - Lady Catherine's nephew, Clarity (Cla.) which illustrate what Elizabeth Bennet means, Accuracy (Acc.) which is verifying the if her meaning is true, and Precision (Pre.) which gives the information why Elizabeth Bennet is not intended to discuss the subject. Meanwhile, for Fitzwilliam Darcy's argument it can be seen as follows.

'I shall not say you are mistaken,' (Sig.) he replied, 'because you could not really believe me to entertain any design of alarming you; ${ }^{(C l a .)}$ and I have had the pleasure of your acquaintance long enough to know that you find great 
enjoyment in occasionally professing opinions which in fact are not your own.' (Pre. )(Chapter 31 p. 150)

In this argument, there are some categories of critical thinking that can be found such as Significance (Sig.) which is the central idea to focus on Mr. Darcy's argument about judging someone if Elizabeth Bennet is right or wrong, Clarity (Cla.) which illustrate what Mr. Darcy means, and Precision (Pre.) which gives the logical reasoning as the example of his information.

The comparison between categories of critical thinking of the main characters occurs because Elizabeth Bennet and Fitzwilliam Darcy have different process of critical thinking (Kallet, 2014:17). Thus, the outcome of the categories of critical thinking can be compared such as follows.

\section{Table 1}

The comparison of Elizabeth Bennet and Fitzwilliam Darcy in Using the Categories of Critical Thinking

\begin{tabular}{|c|c|c|}
\hline \multirow{2}{*}{$\begin{array}{c}\text { Categories of } \\
\text { Critical } \\
\text { Thinking }\end{array}$} & \multicolumn{2}{|c|}{ Characters } \\
\hline & $\begin{array}{c}\text { Elizabeth } \\
\text { Bennet }\end{array}$ & $\begin{array}{c}\text { Fitzwilliam } \\
\text { Darcy }\end{array}$ \\
\hline Clarity (Cla.) & 13 & 4 \\
\hline $\begin{array}{c}\text { Accuracy } \\
\text { (Acc.) }\end{array}$ & 5 & 0 \\
\hline $\begin{array}{l}\text { Precision } \\
\text { (Pre.) }\end{array}$ & 10 & 4 \\
\hline $\begin{array}{c}\text { Relevance } \\
\text { (Rel.) }\end{array}$ & 7 & 3 \\
\hline $\begin{array}{l}\text { Depth } \\
\text { (Dep.) }\end{array}$ & 3 & 0 \\
\hline Breadth (Bre.) & 4 & 0 \\
\hline $\begin{array}{c}\begin{array}{c}\text { Logic } \\
(\log .)\end{array} \\
\end{array}$ & 1 & 1 \\
\hline $\begin{array}{l}\text { Significance } \\
\text { (Sig.) }\end{array}$ & 13 & 4 \\
\hline Fairness (Fai.) & 0 & 0 \\
\hline
\end{tabular}
some different categories used by Elizabeth Bennet and Fitzwilliam Darcy. The comparison is acquired based on the characters' arguments, which show the categories of critical thinking of the characters, because Elizabeth Bennet's arguments represent high usage of the categories of critical thinking than Fitzwilliam Darcy's arguments. Therefore, after indicating the result about the categories of critical thinking above, this study comes to the resolution of the first research question that this study identifies the description about specific categories of critical thinking, such as clarity, precision, accuracy, relevance, depth, breadth, logic, and significant, in the characters' arguments based on the universal intellectual standards (Paul and Elder, 2009:10).

Based on the second problem statement, the finding about the kinds of arguments in critical thinking are recognized based on the kinds of argument, according to Waller (2012:19), which are inductive and deductive arguments. Through the discovering process, the researcher acquires the two kinds of arguments based on the structure and the indicator of argument. The two kinds of arguments are the inductive and deductive argument. Those arguments have different indicators even though the result shows that those arguments have the same structure. Therefore, the inductive argument of Elizabeth Bennet can be seen in the following transcript as follow.
The table 1 above shows that there are

'Pray, my dear aunt, what is the difference in matrimonial affairs, between the mercenary and the prudent motive?

Where does discretion end, and avarice begin?

Last Christmas you were afraid of his marrying me, because it would be imprudent; and now, because he is trying to get a girl with only ten thousand pounds, you want to find out that he is mercenary.' (Chapter 27 p. 130) 
This argument is an inductive argument because the information stated in the premises has been abridged clearly in the conclusion. Therefore, the argument structure in this argument is PremisesConclusion (P-C), which has been stated briefly by some statements (P1-P2), which are comparing some realities through the statements that finally have been concluded by a standalone statement $(\mathrm{C})$. Based on this argument, the illustration of the argument structure can be seen as follows.

Figure 1

The Inductive Argument Structure of Elizabeth Bennet

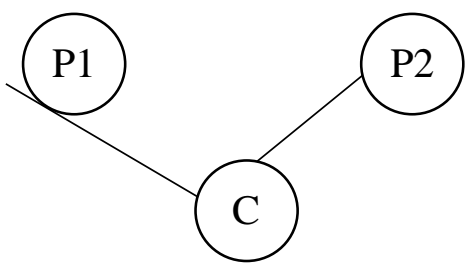

Through Elizabeth Bennet's arguments in Pride and Prejudice, this study discovers some argument structures such as Premise(s)-Conclusion (P-C), ConclusionPremise(s) (C-P) and Premise(s)Conclusion-Premise(s) (P-C-P). Meanwhile, for Fitzwilliam Darcy's argument, this study discovers some structures such as Premise(s)-Conclusion (P-C), and Premise(s)-Conclusion-Premise(s) (P-C-P), which can be seen in the following transcript.

'The indirect boast; for you are really proud of your defects in writing,

because you consider them as proceeding from a rapidity of thought and carelessness of execution, which, if not estimable, you think at least highly interesting. ...'(Chapter 10 p. 43)

This argument is an inductive argument, because the information stated in the premise (C) about proud of defects in writing has been summarized clearly as the conclusion $(\mathrm{P})$, which is about the proud of defects in writing. The argument structure is Conclusion-Premise(s) (C-P), because the information stated in the premises has a reasonable statement. This argument's structure can be illustrated as follow.

Figure 2

\section{The Inductive Argument Structure of} Fitzwilliam Darcy

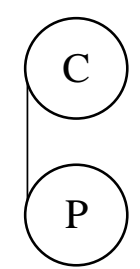

The discussion above represents about the inductive argument. Meanwhile, the deductive argument emphasizes the statements called as premises are used as the base of an argument. The indicators of deductive argument have played its role for the researcher to attain the results of this problem as stated in problem statement. Therefore, the following discussion is intended to describe and to explain the kinds of deductive argument used only by Elizabeth Bennet.

'You may as well call it

impertinence at once. It was very little less.

The fact is, that you were sick

of civility, of deference, of officious attention.

You were disgusted with the women who were always speaking, and looking, and thinking for your approbation alone.

I roused, and interested you, because I was so unlike them. ...' (Chapter 60 p. 318)

This argument is a deductive argument because the statement (P1) tells directly 
about Elizabeth Bennet's assumption about Mr. Darcy, then the following statement (P2) as additional information has supporting information from the statement (P3), which finally has been concluded, as in the conclusion (C). The argument structure of this argument is Premises-Conclusion (P-C). Therefore, the following illustration represents the structure of argument which it can be seen as follows.

Figure 3

The Deductive Argument Structure of Elizabeth Bennet

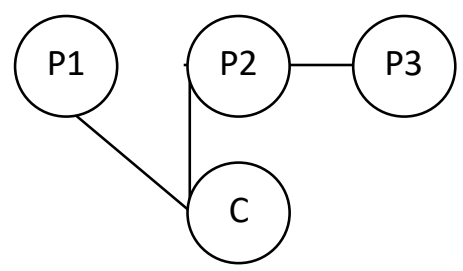

Through the discussion about the kinds of arguments above, this study finds that the inductive argument is highly applied by Elizabeth Bennet and Fitzwilliam Darcy rather than deductive argument. Therefore, as the resolution to the second research problem, this study identifies that the description about the kinds of argument, based on the characters' argument in Pride and Prejudice, are obviously fulfilled by Elizabeth Bennet and Fitzwilliam Darcy in their arguments, which indicates that the inductive argument is mostly used in calculation rather than the deductive argument. The table 2 below shows the comparison of the deductive argument and the inductive argument implemented by Elizabeth Bennet and Fitzwilliam Darcy.

Table 2

The Comparison between Elizabeth Bennet and Fitzwilliam Darcy in Implementing the Kinds of Argument

\begin{tabular}{|c|c|c|}
\hline \multirow{2}{*}{$\begin{array}{c}\text { Kinds of } \\
\text { Argument }\end{array}$} & \multicolumn{2}{|c|}{ Characters } \\
\cline { 2 - 3 } & $\begin{array}{c}\text { Elizabeth } \\
\text { Bennet }\end{array}$ & $\begin{array}{c}\text { Fitzwilliam } \\
\text { Darcy }\end{array}$ \\
\hline Inductive & 4 & 0 \\
\hline
\end{tabular}

\begin{tabular}{|l|l|l|}
\hline Deductive & 9 & 4 \\
\hline
\end{tabular}

Based on the usage of meaning as discourse strategy, it is definitely described that the usage of meaning, which refers to van Dijk's concept (cited in Rosdiana, 2016:43--44), such as implication, presupposition, evidentially, and disclaimer, is obviously identified by analyzing and understanding the characters' arguments related to the usage of meaning as discourse strategy.

'Indeed, Jane, you ought to believe me. No one who has ever seen you together can doubt his affection. ${ }^{(E v .)}$ Miss Bingley, I am sure, cannot. She is not such a simpleton. Could she have seen half as much love in Mr. Darcy for herself, she would have ordered her wedding clothes. But the case is this: We are not rich enough or grand enough for them; (Di.) and she is the more anxious to get Miss Darcy for her brother, from the notion that when there has been one intermarriage, she may have less trouble in achieving a second; in which there is certainly some ingenuity, and I dare say it would succeed, if Miss de Bourgh were out of the way. But, my dearest Jane, you cannot seriously imagine that because Miss Bingley tells you her brother greatly admires Miss Darcy, he is in the smallest degree less sensible of your merit than when he took leave of you on Tuesday, or that it will be in her power to persuade him that, instead of being in love with you, he is very much in love with her friend.' (Di.)

In this argument, there are three meanings stated by the bold sign that represent the usage of meaning of evidence and disclaimers. From the first bold sentence, it can be meaningfully seen that Elizabeth Bennet stresses her idea about the affectation of honestly which is commonly found everywhere. Meanwhile, the second 
bold sentence as presupposition can be assumed that Elizabeth guesses Jane likes Mr. Bingley. Finally, the last bold sentence represents a contrast idea.

'Yes,' replied Darcy, who could contain himself no longer, 'but that was only when I first saw her, ${ }^{(D i .)}$ for it is many months since I have considered her as one of the handsomest women of my acquaintance. ${ }^{\text {'(Ev.) }}$

In this argument, there is only one meaning stated by the bold sign that represent the usage of meaning disclaimer. The sentence meaningfully shows that $\mathrm{Mr}$. Fitzwilliam Darcy's denial supports his first answer which has some evidences as the last statement as his reason. However, based on the explanation about the meaning as discourse strategy, the characters' arguments have different discourse strategy such as implication, presupposition, evidentially and disclaimer, based on the context of the arguments. Therefore, this study discovers that the usage of meaning as discourse strategy has been expressively implemented by Elizabeth Bennet and Fitzwilliam Darcy through their arguments.
Based on the fourth problem statement of this study, it is stated that there are four Discourse Markers (called DMs) such as additive, adversative, causal and temporal (Flowerdew, 2013:38). This study uses Flowerdew's concept to discover the usage of DMs in the characters' arguments in Pride and Prejudice. Both Elizabeth Bennet and Fitzwilliam Darcy have used different kinds of those DMs in their arguments. As a comparison, the recent study of Fatemeh Zarei in Discourse Markers in English (2013), discovered that there are some English discourse markers usage such as and, because, but, I mean, now, oh, or, so, then, well and else. Meanwhile, this study is intended to discover the DMs in the characters' arguments in Pride and Prejudice. The process of collecting the data in the usage of DMs is acquired only based on the acceptable, relevant and good arguments of the main characters' utterances. Therefore, the result of this study shows that the additive DMs is the first category based on its usage as the DMs. Meanwhile, the adversative, the causal and the temporal DMs orderly follow the additive DMs as the second, the third and the fourth category.

Table 3

The Comparison of the Discourse Markers (DMs) Usage in the Characters' Arguments in Pride and Prejudice

\begin{tabular}{|c|c|c|c|c|}
\hline \multirow{2}{*}{ No. } & \multirow{2}{*}{\multicolumn{2}{|c|}{ Discourse Markers (DMs) Indicators }} & \multicolumn{2}{|c|}{ Frequently Usage by Characters } \\
\hline & & & Elizabeth Bennet & Fitzwilliam Darcy \\
\hline \multirow{4}{*}{1} & \multirow{4}{*}{ Additive } & And & 32 & 4 \\
\hline & & In addition & 0 & 0 \\
\hline & & Besides & 0 & 0 \\
\hline & & Furthermore & 0 & 0 \\
\hline \multirow{4}{*}{2} & \multirow{4}{*}{ Adversative } & But & 9 & 1 \\
\hline & & Yet & 0 & 0 \\
\hline & & Though & 0 & 0 \\
\hline & & However & 0 & 0 \\
\hline \multirow{3}{*}{3} & \multirow{3}{*}{ Causal } & So & 1 & 1 \\
\hline & & Then & 0 & 0 \\
\hline & & Therefore & 3 & 0 \\
\hline \multirow{3}{*}{4} & \multirow{3}{*}{ Temporal } & Then & 2 & 0 \\
\hline & & Next & 0 & 0 \\
\hline & & After That & 0 & 0 \\
\hline
\end{tabular}


Totobuang, Vol. 6, No. 2, Desember 2018: 257—267

\begin{tabular}{|l|c|c|c|}
\hline \multirow{2}{*}{ No. } & \multirow{2}{*}{ Discourse Markers (DMs) Indicators } & \multicolumn{2}{|c|}{ Frequently Usage by Characters } \\
\cline { 3 - 5 } & & Elizabeth Bennet & Fitzwilliam Darcy \\
\cline { 3 - 5 } & Finally & 1 & 0 \\
\hline
\end{tabular}

Through the discussion representing the categories of critical thinking, the kinds of argument, the usage of meaning as discourse strategy and the usage of discourse markers, this study finally goes to the main resolution of the general research question about how the critical thinking of the main characters in Pride and Prejudice is. It is identified that the critical thinking of the characters is actually fulfilled by the main characters, who are Elizabeth Bennet and Fitzwilliam Darcy. Therefore, from this discussion, this study has resolved the general problem of the study about the description of critical thinking of the characters based on the acceptable, relevant and good arguments of the main characters.

\section{CONCLUSION}

Based on the result of discussion above, it can be concluded that the categories of critical thinking of the characters in Pride and Prejudice are definitely high. The categories are supported by the categories that are mostly implemented in the characters' arguments. Meanwhile, the kinds of arguments in critical thinking used by the characters in Pride and Prejudice are mostly inductive argument than deductive argument. Then, the usage of meaning as discourse strategy in characters arguments in Pride and Prejudice is definitely various based on the argument's topic. The last, the usage of the discourse markers in the characters' argument in Pride and Prejudice is different in records based on the intention of the characters' arguments.

In conducting this study, the researcher has a difficulty to find a specific data because some arguments of the main characters in Pride and Prejudice consisting of more than one topics. Because of that, the future researchers have to consider the specific topic to discover the outcome of the thinking is intended to be applied for the students, as the academic writers, that the critical thinking can help the students to be the critical thinker in every aspect, especially in the English literature, by analyzing a literary works critically.

\section{REFERENCES}

Angermuller, J., Maingueneau, D., \& Wodak, R. 2014. The Discourse Studies Reader: Main currents in theory and analysis. Amsterdam: John Benjamins Publishing Company.

Bassham, G., Irwin, W., Nardone, H., \& Wallace, J. M. 2011. Critical Thinking - A Student's Introduction(4th ed.). New York: McGraw-Hill.

Bowell, T., \& Kemp, G. 2010. Critical Thinking: A Concise Guide (3rd ed.). New York: Routledge.

Butterworth, J., \& Thwaites, G. 2013. Thinking Skills - Critical Thinking and Problem Solving. Cambridge: Cambridge University Press.

Creswell, J. W. 2009. Research Design:

Qualitative, Quantitative, and Mixed Methods Approaches (3rd ed.). California: SAGE Publications Inc.

Flowerdew, J. 2013. Discourse in English Language Education. Oxon: Routledge.

Govier, T. 2010. A Practical Study of Argument (7th ed.). Belmont: Wadsworth, Cengage Learning.

Graham, M. 2011. Jane Austen: A Study of Film Adaptations. Outstanding Honors Theses. Paper 20., 1-35.

Kallet, M. 2014. Think Smarter: Critical Thinking to Improve Problem-Solving and Decision-Making Skills. New Jersey: John Wiley \& Sons, Inc.

Khatib, M., \& Alizade, I. 2012. Critical Thinking through Literary and NonLiterary Texts in English Classes. 
International Journal of Linguistics, 563-580.

Kohzadi, H., Azizmohammadi, F., \& Samadi, F. 2014. Is there a relationship between Critical Thinking and Critical Reading of Literary Texts: A Case Study at Arak University (Iran). International Letters of Social and Humanistic Science, 63-76.

Moore, B., \& Parker, R. 2012. Critical Thinking. New York: McGraw-Hill.

Nasiroh, Alfiyatun. 2016. Pola dan Kadar Ketajaman Argument ParagrafParagraf Argumentasi Bagian Pembahasan Artikel Jurnal Terakreditasi Bidang Kelautan Tahun 2015. Skripsi. Fakultas Keguruan dan Ilmu Pendidikan. Universitas Sanata Dharma, Yogyakarta.

Paul, R., \& Elder, L. 2009. Critical Thinking - Concepts \& Tools.Tamales: Foundation for Critical Thinking.

Prentice, N. 2016. Thomas Hardy's Tragic Vision: Writing Towards ProtoModernist Modes of Fiction. Bristol: University of the West of England.

Rosdiana, S. 2016. Questioning LGBT Existence in Indonesia: A Critical Discourse Analysis of Discourse Strategies on Live Debate TV One Episode of 'Pernikahan Sejenis'. Semarang: faculty of Humanities, Diponegoro University.

Sheber, S. 2010. Intersections and Implications of Feminist and Marxist Critical Theory in Jane Austen: Persuasion, Pride and Prejudice, and Mansfield Park. Honors Projects. Paper 11., 1-44.

Shukri, A. N., \& Mukundan, J. 2015. A Review on Developing Critical Thinking Skills through Literary Texts. Advances in Language and Literary Studies, 4-9.

Stab, C., \& Gurevych, I. 2014. Identifying Argumentative Discourse Structures in Persuasive Essays. Conference on Empirical Methods in Natural
Language Processing (EMNLP) (pp. 46-56). Doha, Qatar: Department of Computer Science, Technische Universität Darmstadt.

Tung, C.-A., \& Chang, S.-Y. 2009. Developing Critical Thinking Through Literature Reading. Feng Chia Journal of Humanities and Social Science, 287-317.

Waller, B. N. 2012. Critical Thinking: Consider the Verdict (Vol. 6th). New York: Pearson Education Inc.

Wang, X., \& Liu, Y. 2011. Analysis of The Feminism in Pride and Prejudice. Theory and Practice in Language Studies, I, 1827-1830.

Zarei, F. 2013. Discourse Markers in English. International Research Journal of Applied and Basic Sciences, 107-117.

Zhao, H. 2014. The Textual Function of Discourse Markers under the Framework of Relevance Theory. Theory and Practice in Language Studies, 2105--2113 